\title{
PEMBELAJARAN KESENIAN REJUNG \\ MELALUI PENDEKATAN SAINTIFIK UNTUK PENANAMAN NILAI BUDAYA LOKAL DI UNIVERSITAS PGRI PALEMBANG
}

\author{
Fadhilah Hidayatullah
}

Dosen Universitas PGRI Palembang

fadhilahhidayatullah@gmail.com

\begin{abstract}
ABSTRAK
Latar belakang penelitian ini dilandasi oleh pentingnya pewarisan budaya lokal pada seni rejung. Terkait hal tersebut, maka desain pembelajaran vokal dasar seni rejung harus di apresiasi oleh peserta didik. Permasalahan yang dikembangkan yakni aplikasi desain pembelajaran vokal dasar seni rejung di Universitas PGRI Palembang. Teori utama yang digunakan yakni pembelajaran melalui pendekatan saintifik pada seni rejung. Penelitian ini menggunakan metode "action research", sedangkan subjek nya yakni kelas VI.A yang berjumlah 30 mahasiswa. Teknik dalam pengumpulan data yakni menggunakan lembar observasi, kuesioner, serta dokumentasi. Sedangkan analisisnya menggunakan penghitungan data hasil observasi, dan kuesioner. Adapun hasil pada penelitian ini yakni mahasiswa dapat memahami dalam menyanyikan seni rejung. Dengan demikian, hasil dari desain pembelajaran vokal dasar seni rejung menggunakan pendekatan saintifik, pada mahasiswa Prodi Pendidikan Sendratasik Universitas PGRI Palembang dapat di aplikasikan dengan baik.
\end{abstract}

Kata Kunci: pembelajaran vokal dasar seni rejung, dan pendekatan saintifik

\section{ABSTRACT}

The background of this research is based on the importance of local cultural inheritance in art rejung. Related to this, the basic vocal art instructional design rejung should in appreciation by learners. The problems that developed the basic vokal learning design applications rejung art at the University of PGRI Palembang. The main theory is used that is learning through a scientific approach to the art rejung. This study uses "action research", while his subject that VI.A classes totaling 30 students. Technique in which data collection using observation. While the analysis using data calculation results of observation, and questionnaires. The results in this study that students can understand the art of singing a rejung. Thus, the results of the basic vocal art instructional design rejung scientific approach, the students Prodi Sendratasik Education University PGRI Palembang can be applied properly.

Keywords: learning basic vocal art rejung, and scientific approach

\section{PENDAHULUAN}

Rejung merupakan salah satu nama kesenian etnik Semende, yang ada di daerah Provinsi Sumatera Selatan. Bentuk kesenian ini berupa pantun yang ditembangkan, dan berperan sebagai media komunikasi. Kesenian ini merupakan sebuah seni vokal yang mempunyai ciri khas pada kenjun dan syair yang menggunakan dialek etnik Semende.

Masyarakat etnik Semende memaknai kenjun sebagai naik turunnya nada dalam sebuah nyanyian yang sedang dibawakan. Maka dari itu, setiap kenjun yang dibawakan oleh seniman tidaklah sama, karena berdasarkan karakter vokal masing-masing penyaji.
Keutamaan dari penyajian kesenian rejung adalah pada keindahan ornamen vokalnya. Keindahan tersebut dapat di pelajari melalui pendidikan formal, yakni pada institusi pendidikan. Dengan demikian, maka dapat dijadikan sebagai materi pembelajaran. Agar pelaksanaan pembelajarannya berlangsung secara efektif, maka perlu didesain konsep pembelajaran secara khusus. Salah satu modal pembelajaran yang akan digunakan yakni pendekatan saintifik.

Pendekatan saintifik adalah pendekatan sebuah pembelajaran yang bersifat ilmiah. Senada dengan itu maka Barringer, et al., dalam Abidin, Y., (2014, hlm. 125) 
menyatakan bahwa pembelajaran saintifik yakni pembelajaran yang menuntut siswa berfikir secara sistematis dan kritis dalam upaya memecahkan masalah yang penyelesaiannya tidak mudah dilihat. Seperti yang diungkap oleh Abidin, Y., (2014, hlm. 126) bahwa dalam kegiatan pembelajaran saintifik akan melibatkan siswa dengan kegiatan yang memecahkan masalah secara kompleks melalui kegiatan curah gagasan, berfikir kreatif, melakukan aktivitas penelitian, dan membangun konseptualisasi pengetahuan.

Pernyataan mengenai pendekatan pembelajaran saintifik tersebut, Muhajir dan Rulani Khatimah, Y., (2014, hlm. 50) menyatakan bahwa langkah-langkah pembelajaran pada pendekatan saintifik, akan menyentuh tiga ranah, yaitu sikap (afektif), pengetahuan (kognitif), dan keterampilan (psikomotor). Sasaran pada kegiatan pembelajaran saintifik mencakup pengembangan dari ketiga ranah tersebut yang dielaborasi untuk setiap satuan pendidikan. Proses pembelajaran tersebut diharapkan akan melahirkan peserta didik yang produktif, kreatif, inovatif, dan afektif.

Pendekatan saintifik dalam pembelajaran sebagaimana dimaksud Muhajir dan Rulani Khatimah, Y., (2013, hlm. 50) adalah dengan menggali informasi melalui pengamatan, bertanya, menalar, percobaan, mengolah data, serta menyajikan data atau informasi. Selanjutnya, dengan menganalisis, menalar, kemudian menyimpulkan, dan mencipta. Kemendikbud (dalam Abidin, Y., 2014, hlm. 133) menyajikan pendekatan saintifik dalam pembelajaran, yakni (1) mengamati; (2) menanya; (3) menalar; (4) mencoba; (5) menyimpulkan; dan (6) mengomunikasikan.

Dengan menggunakan pendekatan tersebut dalam proses pembelajaran, maka dapat menghasilkan konsep pembelajaran kesenian rejung dan tentunya mengacu pada pendekatan saintifik. Maka dari itu, desain konsep pembelajaran kesenian rejung, akan

Bagan 1

Sintak pembelajaran saintifik

Sumber: Abidin,Y.

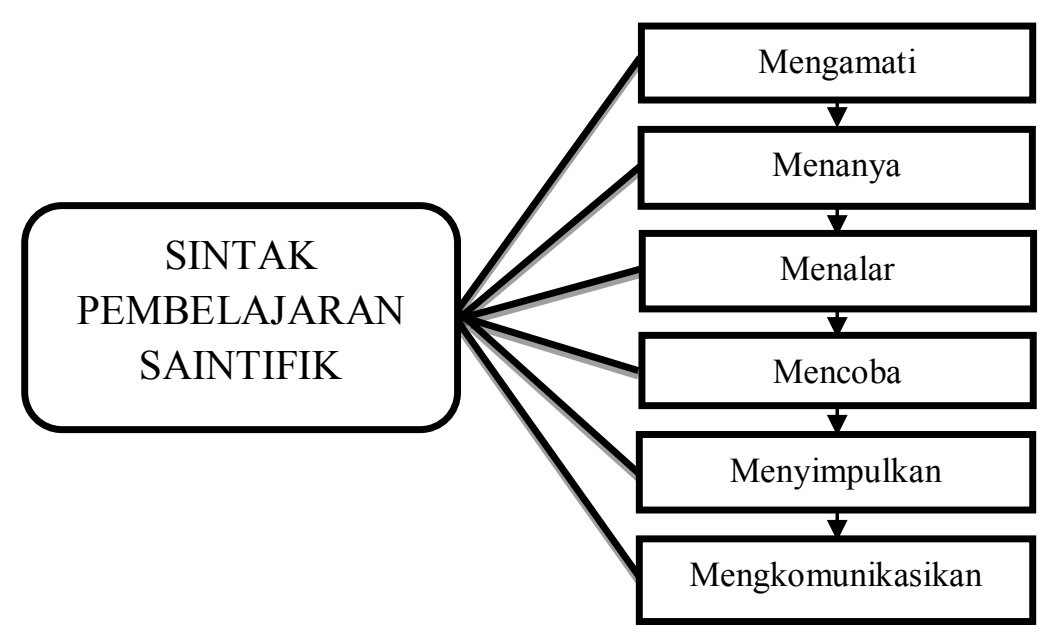

menggunakan pendekatan saintifik, seperti pada bagan sebagai berikut.

Melalui pendekatan saintifik ini sangat tepat diterapkan di perguruan tinggi, karena untuk membekali mahasiswa calon guru, sehingga orientasinya pada karakter dan budaya lokal, tercermin pada peserta didik nantinya.
Sehingga dengan menggunakan pendekatan saintifik dalam proses pembelajaran seni, maka dapat menghasilkan konsep pembelajaran seni berbasis seni tradisi.

Salah satu institusi, Prodi Pendidikan Sendratasik, Universitas PGRI Palembang, sudah melangsungkan proses pembelajaran 
kesenian rejung. Pelaksanaan berlangsung disetiap semester enam, melalui Mata Kuliah Tembang Batanghari Sembilan. Namun, dalam beberapa hal tertentu, ada yang belum tersampaikan dengan baik terhadap mahasiswa, pada materi dan tahapannya.

Sampai saat ini, konsep pembelajaran kesenian rejung belum pernah dilakukan, oleh karena itu melalui eksperimen ini peneliti akan mencoba mengembangkan pembelajaran seni rejung melalui pendekatan saintifik melalui bentuk eksperimen. Tujuan mengembangkan desain pembelajaran kesenian Rejung tersebut yakni mengusung pewarisan budaya lokal, serta memberi pemahaman kepada para mahasiswa agar dapat mencintai kesenian daerah, khususnya kesenian rejung. Penelitian dilakukan pada Pendidikan Sendratasik, Universitas PGRI Palembang, karena ada persebaran kurikulum, yang berhubungan dengan program penelitian, yang dikembangkan. Selain itu, membekali mahasiswa tentang konsep pembelajaran berbasis kesenian tradisi, sehingga dapat memumpuni sebagai calon pendidik seni.

\section{METODE PENELITIAN}

Penelitian ini menggunakan metode Action Research, yang merupakan penelitian tindakan. Taniredja (2010, hlm. 15) mengemukakan bahwa penelitian tindakan adalah sebuah strategi pemecahan masalah yang memanfaatkan tindakan nyata dan proses pengembangan kemampuan dalam mendeteksi memecahkan masalah. Arikunto (2008, hlm. 16), menyatakan empat aspek pokok dalam penelitian tindakan yaitu (1) perencanaan; (2) pelaksanaan; (3) pengamatan; dan (4) refleksi. Selanjutnya Alwasilah (2011, hlm. 148) juga menegaskan action research berarti melakukan beberapa action, yang direncanakan, dilakukan, diobservasi, dan direfleksi.

Penelitian ini dilakukan di Universitas PGRI
Palembang. Fokus penelitiannya yakni pada Prodi Pendidikan Sendratasik kelas VI.A yakni konsentrasi tari yang berjumlah 30 mahasiswa. Sedangkan instrumen pada penelitian ini yakni observasi, kuesioner, dan dokumentasi.

Adapun untuk menghitung data observasi dilakukan dengan cara menghitung jawaban "ya", yang di isi oleh pengamat pada format keterlaksanaan pembelajaran. Selanjutnya melakukan perhitungan persentase aktivitas mahasiswa dalam pelaksanaan pembelajaran dengan menggunakan rumus berikut:

Persentase keterlaksanaan $=\frac{\text { Indikator pencapaiar }}{\text { jumlah indikator }}$

Kemudian dalam menganalisis kuesioner dilakukan dengan cara sebgai berikut. Menganalisis data yang didapat dari responden, melalui pretest dan postest, dilakukan dalam beberapa langkah. Langkah pertama adalah dengan cara mengelompokan jawaban responden. Pengelompokan jawaban responden, yakni dengan menghitung jawaban per items, berupa jawaban "ya" dan "tidak". Masing-masing jawaban per items tersebut, dihitung sesuai dengan jumlah hasil jawaban "ya" dan hasil jawaban "tidak". Maka dari itu, seluruh yang menjawab "ya" dan "tidak", akan dijumlahkan sesuai dengan data yang didapat dari responden.

Setelah hasil jawaban semua items telah dihitung, dan dikategorikan, lalu dilanjutkan dengan menghitung persentase ketercapaian disetiap masing-masing items. Untuk itu, cara

Persentase Ketercapaian $=\frac{\text { Jumlah pencapaian has }}{\text { Jumlah kes }}$

menghitung persentase ketercapaian disetiap items, menggunakan rumus berikut ini.

Setelah hasil presentase ketercapaian telah diperoleh, lalu menghitung jumlah rata-rata persentase dari ketercapaian yang didapat.

Jumlah rata - rata persentase ketercapaian $=\frac{\text { Jumlah persentase ketercapaian }}{\text { Jumlah keseluruhan items }}$ 
Agar diketahui jumlah rata-rata persentase ketercapaian tersebut, digunakan rumus berikut ini.

Sedangkan data yang didapat melalui dokumentasi, terlepas dari hitungan. Dilakukan dengan mengumpulkan semua yang didapat terlebih dahulu, kemudian mengelompokan sesuai dengan jenis dan kategorisasinya. Data yang terkumpul dan dikelompokan, dimaknai berdasarkan pengamatan yang dilakukan. Setelah data dimaknai berdasarkan kategori dan jenisnya, lalu diinterpretasikan kedalam bahasa Indonesia yang baku. Selanjutnya digunakan sesuai dengan kebutuhan pada penyusunan laporan, dengan teknik deskriptif analisis, yaitu dengan cara mendeskripsikan keterangan-keterangan atau data-data yang telah terkumpul.

\section{HASIL DAN PEMBAHASAN}

\section{Hasil}

Desain pembelajaran pada materi vokal dasar seni rejung diaplikasikan selama dua pertemuan. Pertemuan pertama diaplikasikan pada siklus pertama, dilanjutkan siklus dua yang melaksanakan perbaikan terhadap

Tabel 1

Hasil aplikasi desain pembelajaran vokal dasar seni rejung (siklus satu)

\begin{tabular}{llcccc}
\hline \multirow{2}{*}{ No } & \multirow{2}{*}{ Ranah } & \multicolumn{4}{c}{ Total pencapaian } \\
& & Siklus satu \\
\cline { 3 - 6 } & & Amat Baik & Baik & Cukup & Kurang \\
\hline 1 & Afektif & $89 \%$ & $11 \%$ & $0 \%$ & $0 \%$ \\
\hline 2 & Psikomotorik & $9 \%$ & $58 \%$ & $6 \%$ & $27 \%$ \\
\hline 3 & Kognitif & $11 \%$ & $89 \%$ & $0 \%$ & $0 \%$ \\
\hline
\end{tabular}

indikator yang belum tuntas. Hasil yang akan dipaparkan adalah terkait dari siklus satu dan dua, yakni sebagai berikut. seni rejung pada ranah "psikomotorik", ditunjukan pada kategori "amat baik" $9 \%$, kategori "baik" $58 \%$, kategori "cukup" 6

Aplikasi desain pembelajaran vokal dasar

Tabel 2

Hasil perbaikan aplikasi desain pembelajaran vokal dasar seni rejung (siklus dua)

\begin{tabular}{lcccc}
\hline \multirow{2}{*}{ Ranah } & \multicolumn{4}{c}{ Pencapaian Dari Perbaikan } \\
\cline { 2 - 5 } & Amat Baik & Baik & Cukup & Kurang \\
\hline Afektif & $92 \%$ & $8 \%$ & $0 \%$ & $0 \%$ \\
\hline Psikomotorik & $17 \%$ & $83 \%$ & $0 \%$ & $0 \%$ \\
\hline Kognitif & $28 \%$ & $72 \%$ & $0 \%$ & $0 \%$ \\
\hline
\end{tabular}

\%, dan kategori "kurang” $27 \%$. Maka dari itu, hasil dari perbaikannya yakni sebagai berikut.

Perbaikan berpengaruh pada seluruh indikator ketiga ranah pembelajaran. Sehingga

Tabel 3

Hasil aplikasi desain pembelajaran vokal dasar seni rejung

\begin{tabular}{clcccc}
\hline \multirow{2}{*}{ No } & \multirow{2}{*}{ Ranah } & \multicolumn{3}{c}{ Total Pencapaian } \\
\cline { 3 - 6 } & & Amat Baik & Baik & Cukup & Kurang \\
\hline 1 & Afektif & $92 \%$ & $8 \%$ & $0 \%$ & $0 \%$ \\
\hline 2 & Psikomotorik & $17 \%$ & $83 \%$ & $0 \%$ & $0 \%$ \\
\hline 3 & Kognitif & $28 \%$ & $72 \%$ & $0 \%$ & $0 \%$ \\
\hline
\end{tabular}
sebelumnya. Setelah dilakukan perbaikan pada siklus dua, maka akan digabungkan kembali ketercapaian dari total persentase seluruh ranah (afektif, psikomotorik, dan 
kognitif). Maka hasil yang diperoleh dari aplikasi vokal dasar seni rejung yakni sebagai berikut.

Masing-masing ranah afektif, psikomotorik, dan kognitif memperoleh hasil dengan kategori "amat baik" dan "baik". Kedua kategori tersebut dipaparkan sebagai berikut.

Ranah afektif dikategorikan "amat baik" dengan 92\%. Hasil tersebut diperoleh dari pencapaian ketiga indikator, yakni sebagai berikut: 26 mahasiswa merespon penyampaian dosen, ditunjukkan $87 \%$. Kemudian 27 mahasiswa juga dapat mendengarkan lagu dengan seksama, ditunjukkan 90\%. Selanjutnya 30 mahasiswa dapat toleran dalam kegiatan diskusi, ditunjukkan $100 \%$. Berdasarkan teknik hitungan data, maka jumlah dari seluruh persentase yang diperoleh, di bagi dengan seluruh indikator pencapaian. Berdasarkan hasil yang diperoleh dari ranah afektif, kecenderungan sikap mahasiswa terhadap pembelajaran vokal dasar seni rejung diikuti dengan "amat baik".

Sedangkan kategori "baik" pada ranah afektif diperoleh 8\%. Hasil tersebut diperoleh dari pencapaian ketiga indikator, yakni sebagai berikut: 4 mahasiswa merespon penyampaian dosen, ditunjukkan 13\%. Kemudian 3 mahasiswa juga dapat mendengarkan lagu dengan seksama, ditunjukkan $10 \%$. Selanjutnya 0 mahasiswa dapat toleran dalam kegiatan diskusi, ditunjukkan $0 \%$. Berdasarkan teknik hitungan data, maka jumlah dari seluruh persentase yang diperoleh, di bagi dengan seluruh indikator pencapaian. Maka hasil ditunjukkan dengan: sikap mahasiswa terhadap pembelajaran vokal dasar seni rejung pada kategori "baik" lebih rendah dari pada amat baik. Dengan demikian, disimpulkan bahwa pada ranah afektif, semua mahasiswa cenderung amat baik dalam mengikuti pembelajaran vokal dasar seni rejung yang di aplikasikan pada mahasiswa kelas VI.A (konsentrasi tari),
Prodi Pendidikan Sendratasik Universitas PGRI Palembang.

Kemudian dilanjutkan pada ranah psikomotorik yang diperoleh pada kategori "amat baik" yakni 17\%, serta kategori "baik" diperoleh 83\%. Hasil dari kategori "amat baik" diperoleh dari pencapaian ketiga indikator, yakni sebagai berikut: 5 mahasiswa yang mampu membuat syair yang di dengar, ditunjukkan 17\%. Kemudian 5 mahasiswa yang mampu menanggapi seni rejung yang didengarkan, ditunjukkan 17\%. Selanjutnya 5 mahasiswa yang mampu menirukan vokal seni rejung dengan syair baru, ditunjukkan 17\%. Berdasarkan teknik hitungan data, maka jumlah dari seluruh persentase yang diperoleh, di bagi dengan seluruh indikator pencapaian.

Sedangkan hasil dari kategori "baik" diperoleh dari pencapaian ketiga indikator, yakni sebagai berikut: 25 mahasiswa yang mampu membuat syair yang di dengar, ditunjukkan 83\%. Kemudian 25 mahasiswa yang mampu menanggapi seni rejung yang didengarkan, ditunjukkan $83 \%$. Selanjutnya 25 mahasiswa yang mampu menirukan vokal seni rejung dengan syair baru, ditunjukkan $25 \%$. Berdasarkan teknik hitungan data, maka jumlah dari seluruh persentase yang diperoleh, di bagi dengan seluruh indikator pencapaian. Maka, hasil dari ranah psikomotorik ditunjukkan bahwa: kemampuan mahasiswa terhadap pembelajaran vokal dasar seni rejung pada kategori "baik" lebih tinggi dari pada kategori "amat baik". Disimpulkan bahwa pada ranah psikomotorik, semua mahasiswa cenderung mampu dalam mengikuti pembelajaran pengenalan seni rejung, yang di aplikasikan pada mahasiswa kelas VI.A(konsentrasi tari), Prodi Pendidikan Sendratasik Universitas PGRI Palembang.

Ranah kognitif yang diperoleh pada kategori "amat baik" diperoleh dari pencapaian ketiga indikator, yakni sebagai berikut: 15 
mahasiswa yang dapat memahami proses berkreativitas dalam menciptakan syair seni rejung, ditunjukkan $50 \%$. Kemudian 5 yang dapat memahami melodi vokal seni rejung untuk ditransferkan pada syair yang baru, ditunjukkan $17 \%$. Selanjutnya 5 dapat memahami cara menyajikan vokal seni rejung dengan syair yang baru, ditunjukkan $17 \%$. Berdasarkan teknik hitungan data, maka jumlah dari seluruh persentase yang diperoleh, di bagi dengan seluruh indikator pencapaian.

Sedangkan hasil dari kategori "baik" diperoleh dari pencapaian ketiga indikator, yakni sebagai berikut: 15 mahasiswa yang dapat memahami proses berkreativitas dalam menciptakan syair seni rejung, ditunjukkan
$50 \%$. Kemudian 25 yang dapat memahami melodi vokal seni rejung untuk ditransferkan pada syair yang baru, ditunjukkan $83 \%$. Selanjutnya 25 dapat memahami cara menyajikan vokal seni rejung dengan syair yang baru, ditunjukkan $83 \%$. Berdasarkan teknik hitungan data, maka jumlah dari seluruh persentase yang diperoleh, di bagi dengan seluruh indikator pencapaian.

Maka, hasil dari ranah kognitif ditunjukkan bahwa: pengetahuan mahasiswa terhadap pembelajaran vokal dasar seni rejung pada kategori "baik" lebih tinggi dari pada kategori "amat baik". Sehingga, mahasiswa yang mendapatkan pengetahuan dalam mengikuti pembelajaran vokal dasar seni rejung, dinyatakan pada kategori "baik" dengan 72

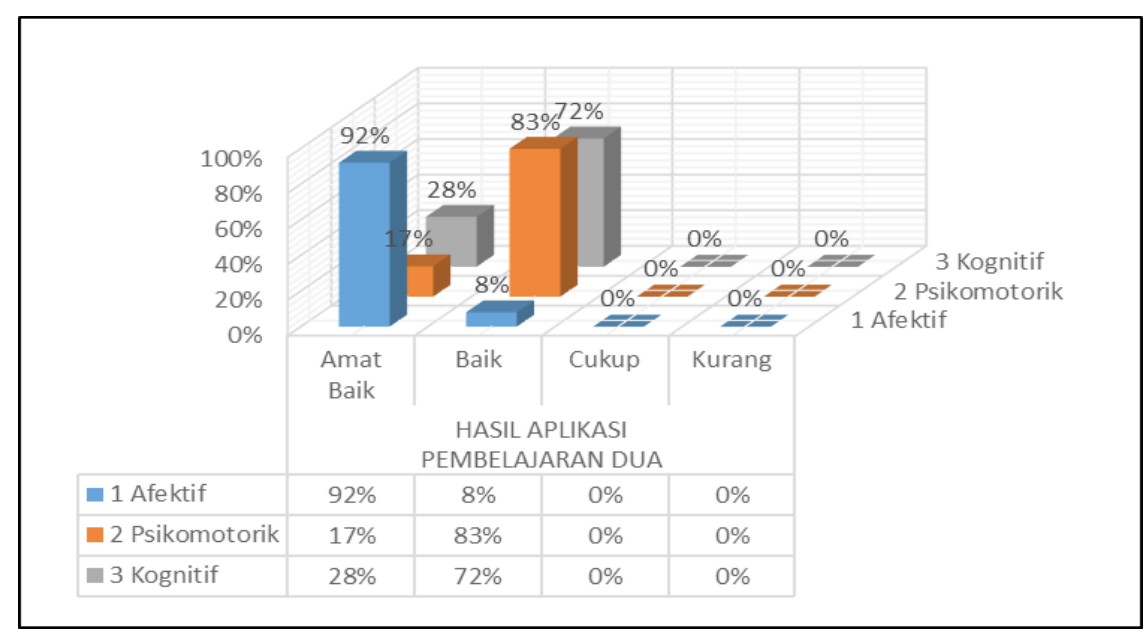

Grafik 1

Hasil aplikasi desain pembelajaran dua (vokal dasar seni rejung)

$\%$. Setelah semua hasil yang diperoleh dari ketiga ranah terhadap pembelajaran vokal dasar seni rejung telah diuraikan, maka diformulasikan sebagai berikut.

\section{Pembahasan}

Pelaksanaan pembelajaran vokal dasar seni rejung menyentuh tiga ranah yakni afektif, psikomotorik, dan kognitif. Ranah afektif yakni pada sikap kepercayaan diri terhadap menuangkan gagasan, pendapat serta antusias dalam mengikuti pembelajaran vokal dasar seni rejung. Kemudian ranah psikomotorik yakni pada kemampuan terhadap menirukan vokal dasar seni rejung. Sedangkan ranah kognitif yakni pengetahuan terhadap vokal dasar seni rejung pada pemahaman yang akan dilakukan selama kegiatan pembelajaran.

Pembelajaran vokal dasar seni rejung harus mencapai keberhasilan terhadap ketiga ranah tersebut. Untuk mencapainya, maka pengaplikasiannya menggunakan pendekatan pembelajaran saintifik. Tahapan pembelajaran saintifik meliputi beberapa kegiatan, yakni: mengamati, menanya, menalar, mencoba, dan mengkomunikasikan. Dengan demikian maka akan dibahas berdasarkan materi yang 
diberikan selama proses pembelajaran. Pelaksanaan terhadap program penelitian yakni pada mahasiswa Prodi Pendidikan Sendratasik Univeritas PGRI Palembang.

Hasil yang diperoleh dari pengaplikasian desain pembelajaran vokal dasar seni rejung dicapai dengan dua kategori yakni amat baik dan baik. Kedua kategori tersebut dicapai oleh ketiga ranah pembelajaran. Ketiga ranah pembelajaran tersebut yakni afektif, psikomotorik, dan kognitif yang mencapai kategori amat baik dan baik. Ketercapaian terhadap kategori pembelajaran amat baik dan baik tersebut karena tingkat indikatornya mudah dipahami dan dilaksanakan oleh mahasiswa.

Kegiatan pembelajaran vokal dasar seni rejung diaplikasikan melalui tahapan saintifik. Tahapan pembelajaran saintifik yang diaplikasikan pada kegiatan pembelajaran vokal dasar seni rejung dapat dilaksanakan dengan baik. Keterlaksanaan pembelajaran melalui pendekatan saintifik terhadap pembelajaran vokal dasar seni rejung menjadi konsep yang baru terhadap pembelajarannya. Hal tersebut karena mahasiswa aktif dalam mengikuti berbagai kegiatannya. Namun kesulitan yang ditemukan bukan menjadi alasan tidak aktif. Keaktifan mahasiswa dalam pembelajaran vokal dasar seni rejung melalui tahapan mengamati, mahasiswa dengan ikut serta serius dalam mengikuti pengamatannya. Kegiatan menanya, mahasiswa aktif dalam kegiatan mengajukan berbagai pertanyaan dan gagasan. Kegiatan menalar mahasiswa mampu berfikir dan menelaah materi yang sedang diberikan. Kegiatan mencoba dan mengkomuniaksikan, mahasiswa mampu menirukan dan menyajikan vokal dasar seni rejung.

Hasil yang diperoleh dari tahapan pembelajaran saintifik tersebut sehingga mengalami perubahan aktifitas menjadi aktif. Keaktifan mahasiswa dalam kegiatan pembelajarannya hasil dari dampak tahapan yang diapliaksikan terhadap pembelajaran seni rejung. Sehingga melalui pengaplikasian desain pembelajaran vokal dasar seni rejung dengan pendekatan saintifik dinyatakan berhasil dan cocok untuk konsep pembelajaran vokal dasar seni rejung.

Kecocokan konsep pembelajaran vokal dasar seni rejung dengan pendekatan saintifik tersebut karena keaktifan mahasiswa terahadap kegiatan pembelajarannya. Dengan kegiatan pembelajaran melalui tahapan saintifik dapat diaplikasikan dengan baik. Hal tersebut menunjukkan bahwa kegiatan pembelajaran vokal dasar seni rejung yang bersifat tradisional dapat dilakukan dengan sistem pembelajaran yang ilmiah. Pembelajaran ilmiah yang diikuti dengan peran mahasiswa yang aktif dalam keterlaksanaan proses pembelajarannya. Sehinga konsep pembelajaran menggunakan pendekatan saintifik dapat diaplikasikan pada vokal dasar seni rejung.

\section{KESIMPULAN}

Hasil yang diperoleh dari aplikasi desain pembelajaran vokal dasar seni rejung yang menggunakan pendekatan saintifik, yakni mahasiswa mendapatkan pengalaman baru terhadap proses apresiasi yang telah dilaksanakan. Kemudian mahasiswa juga mendapatkan stimulan yang dibimbing aktif dalam mengemukakan pendapat terkait dari apa yang telah di apresiasi. Selain itu, mahasiswa juga dituntut untuk memikirkan dari sesuatu hal yang dianggap penting dalam sebuah temuan pembelajaran. Mahasiswa juga tumbuh rasa kepercayaan diri terhadap kemampuan yang ada pada diri masingmasing untuk di apresiasi oleh teman sekelas.

Berdasarkan kegiatan tersebut, hasil yang diperoleh selama kegiatan pembelajaran dapat disimpulkan bahwa mahasiswa berdampak positif dan terdapat peningkatan apresiasi terahadap vokal dasar seni rejung yang telah dipelajari selama proses pembelajaran 
berlangsung. Kesimpulan tersebut didukung pula oleh hasil evaluasi yang diperoleh selama kegiatan pemebelajaran serta hasil dari kuesioner yang telah disebar baik pretest maupun postest. Dengan demikian, apresiasi mahasiswa dinyatakan dapat meningkat.

\section{DAFTAR PUSTAKA}

Abidin, Y. (2014). Desain Sistem Pembelajaran Dalam Konteks Kurikulum 2013. Cetakan Kesatu. Bandung: PT. Refika Aditama.

Alwasilah, A.C. (2011). Pokoknya Action Research. Bandung: PT. Kiblat Buku Utama.

Arikunto, dkk. (2008). Penelitian Tindakan Kelas. Jakarta: PT. Aksara.

Muhajir \& Rulani Khatimah, Y. (2013). Buku Pedoman Pengembangan dan Implementasi Kurikulum 2013. Kementerian Pendidikan dan Kebudayaan Republik Indonesia Unit Implementasi Kurikulum 2013.

Taniredja, T.; Pujianti, I.; \& Nyata. (2010). Penelitian Tindakan Kelas: Untuk Pengembangan Profesi Guru, Praktik, Praktis dan Mudah. Bandung: Alfabeta. 